\title{
Overview of the Implementation of the EU Youth Strategy in the Field of Employment
}

\author{
Siyka Kovacheva ${ }^{1}$ \\ University of Plovdiv, Bulgaria
}

Overview of the Implementation of the EU Youth Strategy in the Field of Employment. This paper provides an overview of the implementation of the EU Youth Strategy for the promotion of youth employment and entrepreneurship in the EU Member States and four non-EU states: Croatia ${ }^{2}$, Montenegro, Norway and Switzerland. It relies upon the National Reports (NRs) presenting the policy initiatives designed and accomplished during the first cycle (2010-2012) in these countries and submitted in response to a questionnaire developed by the European Commission (EC) and an examination of policy documents, academic literature and statistical data. The comparative analysis reveals a shared awareness of the gravity of the problems accumulated in the labour market integration of young people and attests to the enormous efforts put forward on European, national, regional and local levels for overcoming youth disadvantage. It also highlights the opportunities created by sharing good practices and fostering of cooperation among all policy actors for supporting the young generation to make a successful entry in the world of work.

Key words: EU Youth Strategy, youth employment, youth entrepreneurship, policy initiatives

Prehl'ad realizácie mládežníckej stratégie EÚ v oblasti zamestnávania. Tento článok poskytuje prehl'ad realizácie mládežníckej stratégie EÚ na podporu zamestnávania a podnikania mládeže $v$ členských štátoch EÚ a v štyroch nečlenských štátoch EÚ: v Chorvátsku², Čiernej Hore, Nórsku a vo Švajčiarsku. Opiera sa o národné správy (NRs), predstavujúce politické iniciatívy, ktoré boli v týchto krajinách zostavené a realizované počas prvého cyklu (2010-2012) a predložené ako odozva na dotazník, ktorý vytvorila Európska komisia (EC), a o prieskum metodických dokumentov, akademickej literatúry a štatistických údajov. Porovnávacia analýza odhal'uje, že krajiny si uvedomujú závažnost' problémov, ktoré sa nahromadili $v$ oblasti integrácie mladých l'udí do trhu práce, a svedčí o nesmiernej snahe prekonat' znevýhodnenie mládeže na európskej, národnej, regionálnej a miestnej úrovni. Tiež zdôrazňuje príležitosti, ktoré sa vytvorili zdielaním dobrej praxe a podporovaním spolupráce medzi všetkými politickými aktérmi na podporu mladej generácie, aby úspešne vstúpila do sveta práce.

\footnotetext{
1 Address: Siyka Kovacheva, Department of Applied and Institutional Sociology, University of Plovdiv, 24 Tsar Asen Street, Plovdiv 4000, Bulgaria. E-mail: siykakovacheva@gmail.com

${ }^{2}$ Croatia joined the EU in July 2013.
} 
Kl'účové slová: mládežnícka stratégia EÚ, zamestnávanie mládeže, podnikanie mládeže, politické iniciatívy

Making the transition to work remains one of the main channels for young people's social integration in modern societies in East $^{3}$ and West Europe (Roberts, 2009; Jones; 2009; Machacek, 2011). Youth employment or selfemployment allows the young person to achieve economic independence, autonomous status and personal growth, as well as to get engaged in community and societal development. In acknowledgement of the strong impact that the protracted economic crisis is having on young people in Europe worsening their prospects for a successful social integration, the EU Youth Strategy set the promotion of employment and entrepreneurship as the overall priority during the first Trio Presidency (2010-2012) and one of the eight fields of action for the whole period till 2018. Abundant research data draw attention to the disproportionally high youth joblessness which is creating a significant age inequality in the labour market and a threat of social exclusion of a substantial proportion of youth (see for an overview EC, 2013; Kutsar and Helve, 2012; Bell and Blanchflower, 2011). These results were confirmed by the EU Youth Report (EC, 2012a) issued toward the end of the first three-year work cycle by the Council of Europe and the European Commission in September 2012.

This paper gives a comparative overview and analytical assessment of the implementation of the EU Youth Strategy in the field of employment and entrepreneurship based on the National Youth Reports that were elaborated in answer to the comprehensive questionnaire developed by the European Commission. The information base consists of the reports provided by all the EU Member States and four non-EU states: Croatia, Montenegro, Norway and Switzerland (while all EU candidate countries and EFTA countries were invited to submit national reports on a voluntary basis). Besides the rich description of youth policy initiatives given in answer to Section $2 \mathrm{a}$ of the structured questionnaire, this review also builds upon the results presented in the EU Youth Report and made use of the dashboard of youth indicators of Eurostat, the Labour Force Survey (LFS) and Eurostat/UNESCO/OECD online data base on education (EUO). Background information was also gathered

\footnotetext{
${ }^{3}$ Machacek explains the development of unemployment since the change (1989), and he combines it with a detailed analysis of the political course of events and the formation of Slovakian youth policy. It is claimed, in what might seem a contradiction, that instead of seeing unemployment as a political and social problem, it could be considered as 'a new attractive element of the lifestyle [of young people]' (Macháček 2011, p. 88).
} 
from research publications and websites of various research and policy organisations.

The aim of this study is to present in more detail the policy measures and activities taken in European countries for promotion of employability and entrepreneurship among young people. The challenges that this exercise faced were numerous. While the National Reports (NRs) list numerous initiatives, they do not represent an exhaustive picture of the changes in policies that were fostered by the adoption of the EU Youth Strategy in 2010. The information on some initiatives is not detailed enough to allow a systematic application of validation criteria for good practices. Besides, national youth policies vary in their histories and traditions, legal approaches and scope of interventions, division of responsibilities between the main actors and the level of cooperation among them (Williamson, 2008) which have to be taken into consideration when assessing individual projects and measures. Nevertheless, it is possible to draw some conclusions about the relevance and impact of the national efforts done to meet the priority of the Youth Strategy for youth employment and entrepreneurship and hence to contribute to the achievement of the objective for smart, sustainable and inclusive growth of the wider Europe 2020 Strategy.

The promotion of youth employment and entrepreneurship has been realised through a variety of national strategies, specific measures and concrete projects which reflected both the common objectives set up in the EU Youth Strategy and the national traditions and current visions of national policy actors, including young people themselves. In the analysis we focus on six groups of policy initiatives for which answers were provided in the NRs.

\section{Flexicurity strategies}

In the past decades the world of work has been changing rapidly with the massive introduction of new materials and technologies, new communication media and organization of businesses, new occupational skills and values. A major trend in Europe and other developed countries in the world is the rise in the flexibility of work in terms of working time and schedules, working place and mobility, contractual conditions and skills changes, functions and wages. While it creates many opportunities for raising the quality of work, it also leads to labour market segmentation and job insecurity. A crucial policy challenge is how to balance the many forms of flexibility with an equitable security for the employees without the erosion of their rights.

Young people in general are more often found in the flexible patterns of work. Figure 1 allows the comparison between youth and the whole workforce in European countries. The data show clearly that despite the large variations between the countries, in all of them young women and men are more likely 
than the older age groups to be employed on fixed-term contracts. Young people are also disproportionately concentrated in part-time jobs and other flexible forms of contracts such as agency, zero hour, and on-call only. In addition their working schedules are often atypical, including week-end or night-time shifts, as the EU Youth Report (EC, 2012a) underlines.

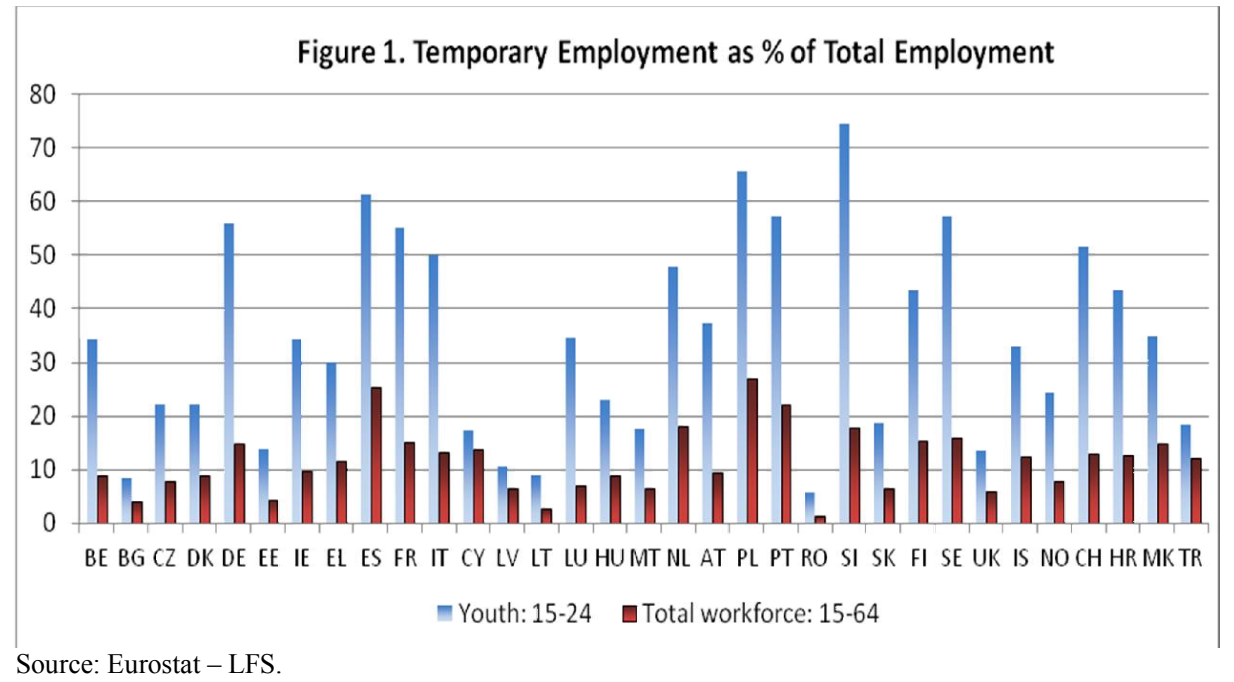

Among the countries giving the answer 'no additional measures necessary', Denmark understandably stands out with the Danish flexicurity model and its long traditions and efficiency proven in the economic downturn in the first half of the 1990s. The model itself matches a high level of flexibility of work with income and employment security and stable welfare schemes (Yorgensen, 2011). In addition, the tailor made initiatives within the active labour market policy focusing on opening new opportunities for the unemployed individual and a stronger coordination between local and national actors contribute to successful employment transitions. The youth specifics of the Danish approach as stated in the Danish NR is the early and active intervention with focus on education and training for all young people and special initiatives for the vulnerable young people to guarantee them a future of education and jobs.

A common move among the countries that have introduced new initiatives in response to the adopted Youth Strategy has been to expand the youth component of the active labour market policies focusing in particular on education, vocational training and counselling, incentives for employers to employ young persons on temporary contracts, subsidized employment for the most vulnerable groups among youth, youth workshops and job fares. Thus in Romania many amendments to the Labour Code were introduced in 2011, 
directed at improving the prospects of young people's integration in the labour market through fixed-term contracts, and these measures were accompanied with vocational counselling, labour mediation and job insertion measures including subsidized loans from the unemployment insurance fund for young people to enrol in higher education institutions.

Some NRs state that the policy discussions on flexicurity in their countries have not gone far in devising special initiatives targeting youth or that the few changes introduced have not had a significant effect. Other NRs raise the awareness that flexicurity cannot be put in place by quick-fix disjointed practices leading to a reduction of the 'security' elements during the economic crisis.

\section{Cross-border professional and vocational opportunities}

The rising international mobility is another manifestation of the flexibilisation of work. The $21^{\text {st }}$ century economy creates a labour market with ever growing requirements for adaptability and resourcefulness from a mobile labour force. Gaining professional and vocational experience in another European country builds up young people's knowledge and skills and makes them more employable in any company settings. The new environment allows young people in particular to learn new ways of working, new ways of organizing their time and activities, new ways of designing aspirations and life plans. The trend toward higher worker mobility gives an advantage to young men and women in Europe because they share an attitude of readiness to explore new work and study opportunities abroad, as shown from the findings of the 2011 Flash Eurobaromenter 319b (EC, 2011). While more than half of young Europeans stated that they were willing to work in another European country, in practice only $10 \%$ have spent time abroad for working purposes.

The answers in the NRs to the specific question about national measures to promote cross-border professional and vocational opportunities for young people present a somewhat different picture from the response on the previous question on flexicurity. The statements that policies for encouraging international exchanges have existed before the adoption of the EU Youth Strategy are 23 out of 33 NRs in comparison with only 13 similar responses to the question on flexicurity initiatives. Even the four reports that gave the answer 'no such plans' have to do more with the understanding that the question concerned nationally designed and funded activities than a total lack of measures promoting international professional and vocational activities of young people. That is why we will first present the most common forms of encouraging youth cross-border mobility here and then focus on some nationally specific measures. 
First of all, most countries stressed the using the opportunities created by the EU programmes such as Youth in Action and Lifelong Learning Programme, with its sectoral programmes Comenius, Erasmus, Leonardo da Vinci and Grundtvig. The Austrian NR cites 'The wind in your back' (RÜCKENWIND) as a successful practice in this field made possible with the support of the Youth in Action. Sweden has carried out an evaluation of the national projects in the field of training supported by Youth in Action and have found their high value added in raising young people's vocational as well as social and language skills. Other European funding opportunities that have been used for cross-border training and job placements for young people are those created by the European Social Fund (ESF). In Germany the 'IdA Integration durch Austausch' made possible through the German ESF specifically targets disadvantaged youth (youth with disabilities, long-term unemployed, early school-leavers, single mothers). Young people are also eligible to draw on job opportunities abroad that are available to all employees and many NRs declare that their policies have actively utilized the EURES network to promote youth mobility. In Belgium, Cyprus, Latvia and Poland international job fairs and workshops updating and training young people for job interviews with foreign employers are organized within this framework. A widely used channel for spreading information about job opportunities abroad and other transnational mobility schemes is Eurodesk which acts in addition to the national and non-governmental portals, websites and other social media cited in the national reports.

The information in the NRs about initiatives funded on a national and regional level is not as abundant as that about projects within EU programmes. The reports from Greece and some East European countries directly state that there are no established forms for cross-border cooperation between neighbouring countries in the field of youth employment and training. In other regions, most notably among the BENELUX countries and among the Nordic countries, cooperation agreements for youth exchanges have existed for decades. The report from the German speaking part of Belgium cites as successful practice the cooperation in the field of professional and vocational mobility within the framework of the Euregio-Maas-Rhein and in the Großregion (Greater region). Policy initiatives from Sweden include organizing of national and world 'skills' championships for young people.

\section{Career guidance and counselling}

This is a traditional field of youth policy in many European countries that needs to be reinforced and remodelled in order to meet the challenges coming from the diversification of youth transition paths and the flexibilisation of labour markets in Europe. High quality counselling and guidance related 
interventions have an economic and social impact measured not only with easily quantifiable indicators of delivery numbers and qualification levels but also with more subtle benefits such as motivating individuals for achievements in further learning and working, enabling their life planning and positively influencing social equality (Hooely and Watts, 2011; Hughes and Graton, 2008).

There is a wide variety of terms in individual EU Member States that regulate and promote this kind of services which include a range of activities that enable citizens to identify their individual capacities, make educational, training and occupational decisions and develop career-management skills. The NRs demonstrate that this objective of the EU Youth Strategy is the policy field that is the most widely accepted and in which most efforts have been invested. Thus all reports either state to have taken enough measures before the adoption of the EU document (25) or that their respective governments have initiated new measures and programmes afterwards (8). A common deduction from all reports is that such services are best developed by means of partnerships between national and regional authorities, guidance practitioners and other social partners in education and employment, and through European cooperation. The NRs also attest to the need for flexibility and diversity of guidance provision and demonstrate the implementation of innovative methodologies and technologies to support young people in their transitions to employment and to adulthood more generally.

In most countries educational counselling and career guidance starts at school. In Sweden, for example, according to the New Education Act which came into force in 2011, access to competent career guidance is offered to every young person at all stages of the educational system - from compulsory schooling to adult education. In Austria a specialized subject 'career guidance and education counselling' was introduced and made compulsory in the 2009/10 school year. At the higher levels of the Austrian educational system a project developed by the Ministry of Education and the Ministry of Science and Research 'Studienchecker' offers guidance on further education and study pathways. There is a similar trend in the new member States. In Latvia elements of career planning and personal development are included in various school subjects as well as in extracurricular activities. The guidance policy in the Czech Republic was given a boost by the 'Career Counselling Project' developed by the University of Masaryk which relied on creating contacts between university students, graduates and employers. In Slovenia in the opinion of young people consulted in writing the NR, however, the well developed career services serve well students in higher education but not those in primary and secondary schools. 
Besides the educational institutions, the Public Employment Agencies are one of the main providers of career guidance in all countries. The recent shifts in their activities include a focus on individualized guidance (Cyprus NR), establishment of a first stop-shop for information on employment opportunities and career prospects (Austrian NR) and developing the Vocational Information Centres (BIZ) which allow clients to choose from a variety of job opportunities, apprenticeships and other initial and specialized training options. In Scotland a new strategy to redesign and improve careers services focused on developing people's ability to manage their own career. The main provider Skills Development Scotland launched a new careers web service 'My World of Work'.

Youth Ministries are another strong partner providing counselling mainly through the Youth Information Centres. In Bulgaria the National Programme (2011-2015) has as its first sub-programme the development of a network of Youth Information and Consultative Centres in all country districts. Such 'Youth Information and Counselling Centres for Choosing a Job' are also operational in the Czech Republic while in Romania such centres act within the framework of the Child Protection Directorate since the current policy in the country places a high significance to the early preparation and developing of skills for independent. In Italy the Youth Department developed a guide 'Good Job' (www.ipotedilavoro) informing and guiding young people through the different legal conditions of the labour contracts and the rights and responsibilities going on with them. Regional authorities also contribute to this policy field. For example in Vienna they established an employment service agency only for young people. Regional development plans in the three linguistic communities of Belgium all address the issues about quality in education, fair access and outcome-based training. In Germany the regional authorities in Hessen, together with the local chambers of crafts, industry and commerce, as well as schools, implement a project for counselling in vocational colleges which is aimed at early recognition and assistance to young people who intend to opt out of school.

European VET policy initiatives, especially within the European qualifications framework for lifelong learning (EQF), and the European credit system for vocational education and training (ECVET) are often cited in the NRs. Estonia acknowledges the support of the ESF for establishing two national programmes 'Development of a System of Career Services' and 'Development of a System of Educational Guidance' aiming not only at young people but also at parents, teachers, and youth workers. The ESF subsidized the Youth Employment Programme in Malta and the KIPNIS project in Latvia for developing careers education guidelines and teacher training for their implementation. With the funding of the European Fund for the Integration of 
Third Country Nationals a new project started in Greece in 2012 with the objective of establishing youth centres in areas with a high rate of migrant population where migrant and local youth will meet and work together.

Significant trend in the provision of counselling and guidance is the greater attention paid to the skills of the professionals working in counselling services (CEDEFOP, 2009). With this objective in Hungary a national network of such experts and a career guidance web portal were set up. The issue of professional training for counsellors is raised in the Swedish NR as well. Some NRs (Finish NR, Croatian NR) give account of renewed efforts to develop the evidence base of the guidance policy by conducting yearly surveys of the vocational aspirations of pupils in primary and secondary schools or the needs of young unemployed. These research results are then submitted to stakeholders on a national and regional level. In this way the counselling services are becoming more responsive and better targeted to specific groups among youth.

\section{Promoting quality internships and apprenticeships}

Closely related to the youth policy field of career guidance and counselling is the provision of apprenticeships and internships, because these forms of job placements in real work settings allow young people to acquire firsthand knowledge of occupations, business companies and economic sectors, to explore career alternatives and orient themselves better in the world of work. Apprenticeships have a long tradition in Europe, as part of the formal vocational education and training involving a period of technical training in a specific occupation which can be solely a school-based programme or combined school and work-based programme. Internships are a more recent form of learning experience as part of the higher education system allowing students to work in a professional setting. A visible trend under the conditions of contracting labour markets is the proliferation of apprenticeships and traineeships offered in various forms and by numerous institutions. The underdeveloped legal basis of internships in many countries allow some companies to replace paid positions with a regular intake of unpaid interns or reduce the learning dimension of the programmes by allotting interns to tasks that do not contribute to the acquisition of professional skills. Other deficiencies of the system are the lack of adequate funding, low transferability of skills gained in one enterprise to other companies, strong imbalance in terms of gender, ethnicity, disability and other problems in the fairness of access (EYF, 2011b; EC, 2012a; 2012b).

Similar to the reporting of initiatives for career guidance and counselling, all NRs state that the countries have taken measures in this field either before (25 NRs) or after (7) the adoption of the EU Youth Strategy. Most efforts have been directed at taking legal measures to regulate the conditions for provision 
and the quality of training, increase the places offered and provide adequate funding.

Legal changes have been carried out in several countries. In Finland regulatory measures were taken to ensure that companies that have done layoffs for economic reasons in the previous 9 months cannot sign an agreement for traineeships with the aim to prevent replacing regular workers with interns. In a similar direction was the royal decree in Spain for the modernization of the social security system in 2011 which made retrospectively participants in training programmes eligible for social security benefits. In France reforms in the system of apprenticeships and internships were carried out in 2011 creating more opportunities for combining studies and training, easier administrative procedures and opening the apprenticeship system for companies with seasonal employment. An apprenticeship card was introduced which gives advantages to trainees similar to those of the holders of student cards. Sweden implemented a change in legislation according to which the apprenticeship during upper secondary school became a permanent alternative to higher education. For the period 2011-2014 this measure is funded with 86 mln EUR. In addition, a job guarantee is offered to those young people registered as unemployed for more than 3 months. Thus in 2010 training was provided for 47000 young people of whom $41 \%$ were women and $59 \%$ men.

Raising the quality of the internships and apprenticeships was the object of particular efforts in most countries in the reporting period. Thus in Wales a recent restructuring of the apprenticeship system aimed to improve the prospects of young people while keeping the options for adults open. This led to a significant increase in the success rates - as the UK NR states, $75 \%$ of learners achieved a full certificate. Under preparation is a 'gold standard' for vocational competence with the objective to raise the quality of apprenticeships. New initiatives include the creation of a web based apprenticeship vacancy system, the practice of sharing apprenticeships between employers and the Pathways to Apprenticeships Programme which places more efforts in the preparation of young people for apprenticeships before going to the real work setting. The need of monitoring internships is underlined in the Lithuanian NR which acknowledges the great variation in the quality of internships offered by different institutions.

Funding remains a problem in some countries vis-à-vis the growing demand for traineeships under the conditions of a tight labour market. Apprenticeships and internships are financed from national public sources - educational, employment and youth sectors; from private businesses and European funds. Increasingly parents are contributing to the costs of practical training. Many NRs (Estonia, Cyprus, Italy and Slovakia) describe projects funded by the ESF in order to widen opportunities for all young people willing to take up such 
training. In Slovenia the Programme 'Employ.me' (ZAPOSLI.ME) targets disadvantaged groups in the labour market, among them young people up to the age of 25 and university graduates without any work experience. The youth representatives contributing to the Slovenian NR answered to this question that the efforts made were not enough and even unpaid apprenticeships did not meet the high demand and many graduates, particularly from social work or health sciences, could not find any placements. In Montenegro in 2011 a new concept on internships was developed to be implemented since 2013. It will allow university graduates to do a 9-month internship with $50 \%$ pay of the salary for the position. Of these training places $30 \%$ will be in public administration and $70 \%$ in private companies. Additional funding will be secured by the government in the amount of $10 \mathrm{mln}$ EUR.

In some countries it is the traineeships linked to the educational programmes as an optional or compulsory part of academic and/or vocational curricula that are most efficient. In others it is the practical training which is part of the active labour market policies that is seen as the best means to facilitate the labour market integration of young people. There are also traineeships offered in the open market some of which are very attractive while there is a widely shared concern with the inadequacy of the regulations over these forms of provision of work-related experience. Nevertheless most NRs attest to the increase in quality and efficiency of apprenticeships and internships.

\section{Sharing of responsibilities between partners for a work-life balance}

The reconciliation of paid work and unpaid care became a problem in modern societies with the decline of the traditional family model of the male breadwinner and the female career in the home. Achieving a satisfactory balance between employment, family and wider life commitments and avoiding conflict and interference between these life domains is a prerequisite of the successful social integration of young people (Nilsen et al, 2012). Work-andfamily friendly policies include a system of accessible and quality childcare services; income support schemes to increase affordability; various forms of parental leaves; and increased flexibility of work.

There is a wide variation between the provision of early childhood education and care among European countries, as seen in Figure 2. In some of them such as Belgium, Spain and France, the enrolment of children as early as 3 years of age is very high, reaching a rate of almost all children in the relevant age group, while in others such as Turkey, Greece and Croatia it is very low and remains so even in the older age groups. The level of satisfaction with the affordability of childcare varies between countries somewhat independently of the rate of enrolment of young children. Most satisfied with the provision are 
respondents in Slovakia, Sweden and Austria and the least in Ireland, Bulgaria, Greece and Malta.

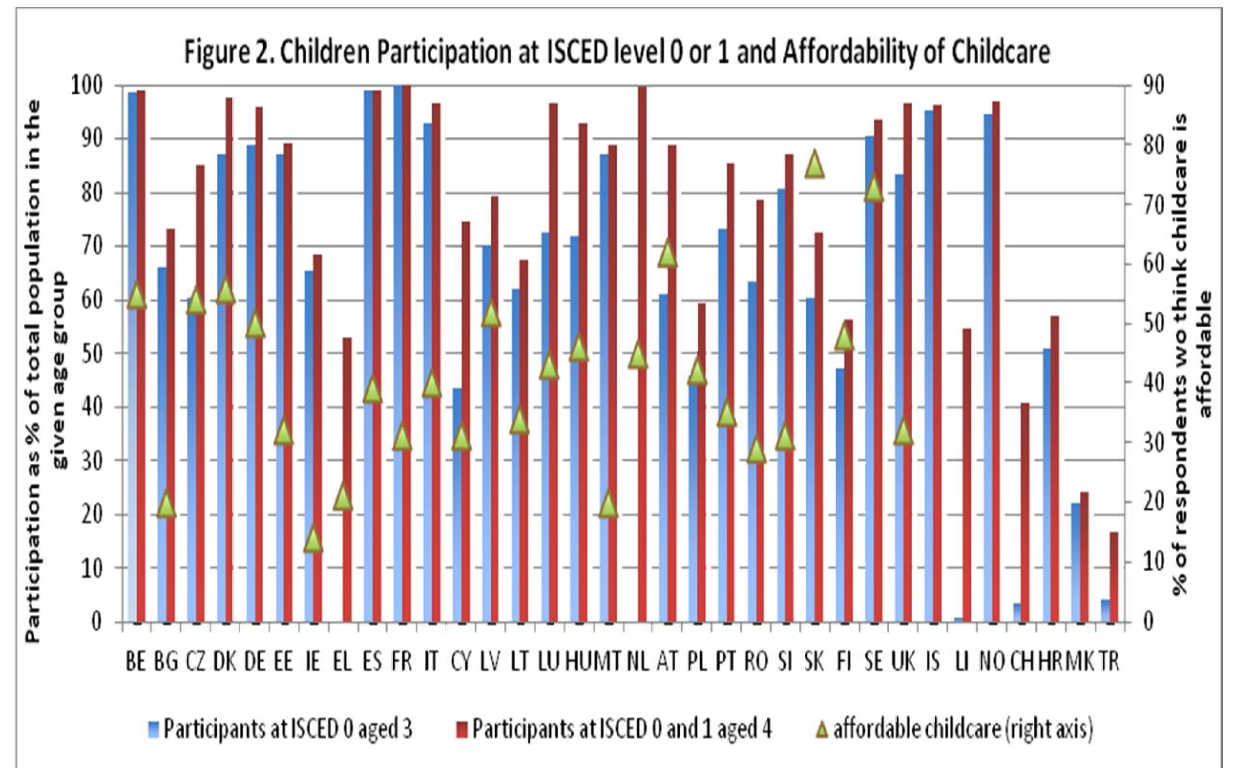

Sources: Eurostat - UEO, and 2010 Special Eurobarometer 355 'Poverty and Social Exclusion'.

The quantitative data in the NRs responding to the question about the forms of support to young parents show that in most countries (25 reports) such measures existed before the adoption of the EU youth strategy. Four countries report that such measures were taken after January 2010; one country, Montenegro, declares that such measures will be included in the new national Youth Policy Plan coming into force in 2013; and three countries, Member States, do not envisage such measures.

The analysis of the NRs indicates that the recent changes in parental leaves are directed towards making them more flexible thus giving more choice to parents. Instead of having a fixed period of leaves after the child birth, parents can decide when and how to use them until the $8^{\text {th }}$ birthday of the child or until it starts school - for example one parent can take the leave part-time, or both parents can take the leave simultaneously. Such measures are reported by Austria, the French- speaking community of Belgium, and the Czech Republic. A high degree of flexibility is characteristic for the parental leave system in Sweden. In this way Swedish parents can choose to be off work for long periods of time, or for single days or part of a day only. This time off may even be saved and used from 60 days before the expected delivery date until the child reaches eight years. Furthermore, there is a possibility of leave and compensation for income loss when a parent takes care of a sick child. 
Financing of parental leaves is perceived as a strategy to encourage a more equal sharing of responsibilities between partners in the family, but also to make it easier for young couples to have the number of children that they wish. With these objectives, Austria raised the payment parents receive during the childcare leave. Tax relief is another financial support measure provided for working parents in many countries. Some national policies have taken measures to widen the eligibility for parental leave to include categories such as the self-employed in Belgium or to offer other forms of career breaks (the Netherlands). In Estonia a working parent is entitled to an additional child care leave of three working days per working year at his or her request if $s /$ he has one or two children under fourteen years of age, and six working days if $\mathrm{s} / \mathrm{he}$ has three or more children under fourteen years of age or at least one child under three years of age.

The introduction of a paternity leave to be taken only by fathers upon the childbirth or soon after is one of the newer measures promoting equal responsibilities between partners. It varies from 2 to 30 days and the financial compensation is also very different. In Poland, for example, a one-week paternity leave was introduced in 2010 and it was prolonged to two weeks in 2012. In Bulgaria and Estonia the periods of maternity leave (reserved for mothers only) were shortened, so that fathers may now use the leave and get involved in childcare much earlier. Besides paternity leave, many policy initiatives encourage gender equality in parenthood by reserving a period of the family leave only for fathers or increasing the paid parental leave if both parents take some of it. Thus in Italy and Germany parental leave schemes grant the couple with a longer paid period if both partners take a portion of the leave. Finland reports that their current efforts in the gender equality policy are concentrated on stimulating fathers' use of parental leave. In 2008, in Sweden a gender equality bonus was introduced in the parental insurance system to encourage parents to share the parental leave. In addition many countries report new or continuing efforts to provide adequate and high quality dependant and childcare services and income support schemes to co-pay for caring services, which as we saw in Figure 2 are still not available and affordable for all parents wishing to use them.

While the current focus of this objective of the EU Youth Strategy is on the gender equal division of tasks in the household, the workplace is not excluded from contributing to it. Thus some measures target business companies in order to provide family friendly policies in the workplace recognizing the responsibilities of young people not only as employees but also as parents. For example Luxemburg is applying the 'Mega Family Company for a WLB' which addresses both families and employers. The project website allows each individual to assess their own situation vis-à-vis the reconciliation of work and 
care. In Slovenia the 'Family-Friendly Enterprise' project, co-funded by the European Social Fund, was designed to tackle a significant obstacle for the reconciliation of work and family life - the widespread attitude among employers that parenthood is disrupting the work process. It includes a competition among companies and awards the certificate 'Family-Friendly Enterprise'. In 2007-2011 more than 90 companies and organisations employing more than 40000 workers received such a certificate. The process of selection is based on the European Work \& Family Audit system developed by the German organisation Berufundfamile. Many governments support the organization of awareness raising campaigns and the publication of promotional materials.

\section{Encouraging entrepreneurship in the field of sustainable development}

Youth self-employment is often pointed at as a solution to mass unemployment at times of economic crises. Youth entrepreneurship, however, is much more than a response to an unfriendly labour market. It is a way for increasing the dynamics and innovation of the economy, a generator of economic and social capital in the community, a field of creativity and empowerment of the entrepreneur. In the case of social entrepreneurship, it contributes to the sustainability of the environment and communities at the local, national and global levels (SALTO, 2011).

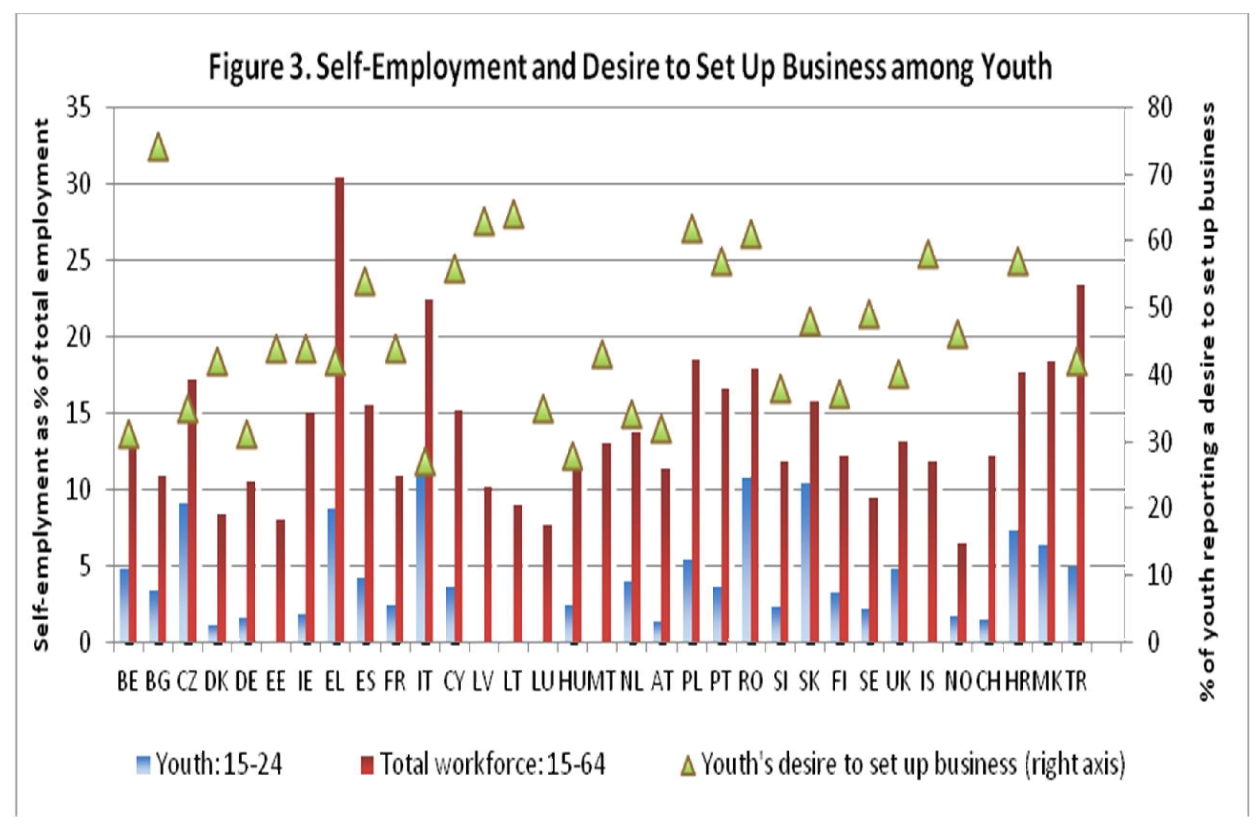

Sources: Eurostat - LFS, and 2011 Flash Eurobarometer 319b 'Youth on the Move'. 
Survey data from Flash Eurobarometer $319 b$ testify that young people express a higher interest in self-employment than older citizens while in practice they are much less self-employed than the adults. Figure 3 compares young people's wish to set up their own business company and the share of those who have succeeded in realizing their wish in practice. Despite variations among countries, in all of them young people are underrepresented among the self-employed and their expressed desire is higher than the actual rate.

NRs demonstrate that the promotion of youth entrepreneurship is a common strategy in European countries. Most answers (25) indicate that such measures have been taken already before 2010, the rest have either made such initiatives in the past two years or plan to do so (two answers for not having current plans).

Many countries report policy measures to develop entrepreneurship skills within the educational system: from broad economic strategies incorporating entrepreneurship education to concrete action plans and programmes. The Lithuanian national education strategy adopted in 2003 was the first to explicitly mention entrepreneurship education. In Croatia an advisory group 'Education for Entrepreneurship' (E4E) was established in 2007 with partners in education, economy, both state and private, also civic associations to promote entrepreneurship education as one of the eight key competences. Following that, in 2010 the government adopted the Strategy for Entrepreneurial Learning for 2010-2014 which envisions cooperation with the Regional Centre for Entrepreneurial Learning in Southeast Europe. The Danish NR indicates that in 2009 four ministries combined their efforts to develop a 'Strategy for Education and Training in Entrepreneurship' including education for sustainable development. Analyzing this field of policy measures it is necessary to stress that although most of them are still directed towards students in vocational schools and universities, there is a shift toward earlier levels of the educational system, primary school in particular. Other recent trends include the application of multidisciplinary approaches and innovative media; and a focus on cooperation of different stakeholders in the development and implementation of the programmes. Many NRs point at the involvement of community, syndicate and business organizations in the education for entrepreneurship. Youth organizations make a significant contribution in the informal learning for entrepreneurship. The Austrian NR underlines the role of youth associations in developing the so-called soft skills, such as ability to communicate with others, handle conflicts, and work in a team and in spreading an attitude against the stigma of failure through encouraging a culture of second and third chances.

Another broad category of policy interventions concerns the provision of information, advice, coaching and mentoring for young people wishing to start 
their own business. Very often such measures are integrated with offering financial support in the form of grants, covering living expenses, micro financing, as well as with developing an adequate infrastructure for entrepreneurship - clubs, conferences, business incubators. Legal changes reducing administrative and tax burden are also adopted for the stimulation of innovation and creativity in business startup and growth. In Belgium most activities in this field are developed at the regional level. Thus in the Frenchspeaking community encouraging ecological entrepreneurship was defined as a priority. The Green Plan Marshall 2 strives to increase eco-investments and innovations by bringing together activities for preserving the environment, employment and entrepreneurship. In 2011 Italy adopted a measure funded jointly by the Youth Department of the government and private businesses with the objective to promote innovative ideas for new enterprises in the field of ecological protection - 'Diritto al futuro'.

Many NRs state that successful entrepreneurship programmes targeting unemployed youth in their countries are operated by the Employment Agencies. The Employment Agency in Lithuania provides subsidies for job seekers who wish to start their own businesses. The new entrepreneurs receive a partial compensation for the income tax and social insurance contributions. Under the programme 'Business Lithuania' many events to promote entrepreneurship among young people are organised. In Bulgaria the Employment Agency implements two schemes for youth entrepreneurship, which are very popular among Bulgarian youth: TECHNOSTART offers grants to young people wishing to develop small technological companies; and JOBS (Job Opportunity through Business Support) helps unemployed young people who wish to start their own business in over 60 municipalities in the country.

The Slovenian NR presents an interesting case for consideration. In the field of sustainable development in 2011 the country adopted "Zakon o socialnem podjetnistvu" - Act on Social Entrepreneurship, which promotes projects with socially useful activities. However, the youth representatives contributing to the NR expressed the opinion that in the business start up initiatives youth has not been defined as a priority group and only a tiny layer among youth has profited from the opportunities. While young people are eligible to use measures devised for all (this is underlined in the German and Finish NRs), it is also necessary to find specific measures to promote entrepreneurship among young people. What is more, such measures should try to reach over the vulnerable groups as well and not only pick up the most promising ideas of advantaged young people. 


\section{Conclusions}

This overview has examined the actions taken by the Member States for the implementation of the overall priority Employment and Entrepreneurship of the EU Youth Strategy in the first cycle of the Open Method of Coordination in the youth field (2010-2012). The analysis started with the actions to improve the employment prospects of young people and ended with the programmes encouraging youth entrepreneurship. Comparing the policy measures on the first Trio Presidency priority, it became clear that the most widely developed by all countries were those in the field of promoting quality internships and apprenticeships and of developing career guidance and counselling services. Such initiatives were part of national youth policies before the entry into force of the EU Youth Strategy but as the results show, most countries have found innovative ways to make them available to more young people, including the most vulnerable. Using the new technologies, youth information centres and public employment agencies have developed interactive websites for labour market information and advice for the new entrants or the unemployed. More attention was given to informal learning and the role that youth organisations play for improving young people's skills and employability. Many countries have established new frameworks for quality provision and control of internships and for the professionalization of the career guidance and counselling. While not all countries designed specific measures to increase flexibility of work and statistical data confirm that indeed there are wide variations in the spread of part-time and fixed-term work in European labour markets, all of them implemented initiatives to provide more security for the young. Several countries have changed their labour codes and introduced tax incentives to stimulate employers for hiring young people.

After 2010 new impetus was given to specific measures for developing entrepreneurship education at all levels of the educational system starting from primary school. The focus on sustainable development when supporting youth entrepreneurial projects is also a novel trend in many parts of Europe. Everywhere special support schemes are designed to widen access to mobility for all young people and not only for a privileged minority. One way to encourage mobility for work and study is to develop measures for the reconciliation of paid work and unpaid care. Most NRs provide information about initiatives to promote the sharing of responsibilities among partners creating equal career and parenting opportunities for both young men and women. A crucial issue here is to increase the affordability, flexibility and quality of childcare services. The novel focus in this policy domain is to tackle inequality in the household and to change outdated models of parental roles. 
The results of the comparative analysis show that the priority of employment and entrepreneurship in the EU Youth Strategy was well accepted by the Member States and beyond and widely implemented in numerous initiatives in support of young people's creative potential. An all-inclusive perspective to policies providing opportunities for all young people to become the new qualified, flexible, and mobile workforce in European economy should be strengthened.

\section{REFERENCES}

Bell, D. \& D. Blanchflower 2011 Youth Unemployment in Europe and the United States, IZA DP No. 5673, http://ftp.iza.org/dp5673.pdf.

CEDEFOP 2009 Professionalising career guidance. Luxembourg: Office for Official Publications of the European Communities.

EACEA 2012 Entrepreneurship Education at School in Europe. National Strategies, Curricula and Learning Outcomes. Luxembourg: Publications Office of the European Union.

EC 2013 Research Focus Employment, Policy Snapshot, Issue 5, March 2013.

EC 2012a Joint Report of the Council and the Commission on the implementation of the renewed framework for European cooperation in the youth field. Luxembourg: Publications Office of the European Union.

EC 2012b Apprenticeship supply in the Member States of the European Union. Final report. Luxembourg: Publications Office of the European Union.

EC 2011 Flash Eurobarometer No 319b Youth on the Move. Analytical Report. Luxembourg: Publications Office of the European Union.

EC 2010 Special Eurobarometer 355 Poverty and Social Exclusion. Luxembourg: Publications Office of the European Union.

EYF, 2011 Interns Revealed. A survey on internship quality in Europe. Brussels: EYF.

Hooely, T. \& A. G. Watts 2011 Careers Work with Young People: Collapse or Transition? International Centre for Guidance Studies Research Papers iCeGS.

Hughes, D. \& G. Gration 2008 Evidence and Impact. Careers and guidancerelated interventions http://www.cfbt.com/evidenceforeducation/pdf/Online\%20resource3.pdf

Kutsar D. \& H. Helve 2012 Social inclusion of youth on the margins of society : policy review of research results. Luxembourg: Publications Office of the European Union.

Jones, J. 2009 Youth. Cambridge: Polity Press.

Machacek, L. 2011 An Introduction to Youth Sociology. Trnava: UCM.

Nilsen, A.; J. Brannen \& S. Lewis (eds) 2012 Transitions to parenthood in Europe. A comparative life course perspective. Bristol: Policy Press. 
Roberts, K. 2009 Youth in Transition Eastern Europe and the West. Basingstoke: Palgrave Macmillan.

SALTO 2011 Inclusion through employability. Youth Work Approaches to Unemployment. Brussels: SALTO.

Williamson, H. 2008 Supporting Young people in Europe. Vol. II. Strasbourg: Council of Europe Publishing.

Yorgensen, H. 2011 Danish "Flexicurity" in Crisis or Just Stress-tested by the Crisis. Report to the Friedrich Ebert Foundation.

Siyka Kovacheva is Associate Professor in sociology and social policy at the University of Plovdiv and Vice Dean of the Faculty of Philosophy and History. She is a member of the Pool of European Youth Researchers of the Youth Partnership between the EU and CoE. Her research interests are in the field of youth transitions to employment and parenthood, civic participation, changes in family life, including gender and intergenerational relations. She has worked on many research and policy projects with the Youth Partnership, the European Youth Forum, the Youth Directorate of the Council of Europe, the $D G$ Education and Culture; DG Employment and Social Affairs and DG Research of the European Commission, Open Society Foundation and other institutions. She is the author of twelve books and many articles and research reports. Her recent books include: Leccardi, C., C. Feixa, S. Kovacheva, H. Reiter, T. Sekulić (Eds.) 2012 1989: Young people and social change after the fall of the Berlin Wall. Strasbourg: Council of Europe Publishing. Chisholm, L., S. Kovacheva, M. Merico (Eds.) 2011 European Youth Studies: Integrating research, policy and practice. E-Reader, Innsbruck: MA EYS consortium. Kovacheva, S. 2010 Work-Life Balance: Young Working Parents between Opportunities and Constraints, Sofia: East-West.

Siyka Kovacheva Department of Applied and Institutional Sociology

University of Plovdiv

24 Tsar Asen Street

Plovdiv 4000

Bulgaria

E-mail: siykakovacheva@gmail.com 